\title{
Cartas aos editores: a necessária interação de leitores com a revista científica
}

\author{
Harley E. A. Bicas
}

Já não é de hoje o reconhecimento nacional e internacional sobre o valor da Oftalmologia brasileira. Em todas as suas diversificadas expressões há sempre representantes de enorme prestígio, lideranças inequívocas, garantindo-nos o respeito e a confiança pelo padrão de excelência no exercício dessa especialidade. Como canal de veiculação de tais práticas e conhecimentos, os Arquivos Brasileiros de Oftalmologia orgulham-se de seus serviços.

Contudo, é sempre possível e necessário melhorar. Ainda há um importantíssimo contingente de nossa melhor produção direcionada a órgãos estrangeiros e cuja incorporação a nossas publicações elevaria ainda mais aqueles bons conceitos já amealhados. Chega-se até a entender as multifacetadas razões determinantes dessas escolhas; as motivações subjacentes a tal sangria, as singulares condições desse estado de coisas que, no fundo, revelam desconfiança no produto nacional e, com isso, perpetuam os mecanismos de subjugação. Todavia essa é uma circunstância cultural, cuja discussão não cabe agora e para que se a supere são exigidas muita paciência e trabalho, persistentes. As colheitas de hoje só são possíveis porque ontem alguém plantou esforços e esperanças; e as de amanhã, também, só eficazes se houver o concurso desta geração que agora passa.

De qualquer modo, o avanço do conhecimento é uma condição quase ontológica, e que portanto flui inercialmente, mesmo com o pouco apoio recebido, ficando quase supérfluo incentivá-lo. E se, por outro lado, a contingência cultural é sujeita a transformações, talvez valha a pena insistir mais e melhor nesta vertente para se chegar ao desejado aprimoramento de nossos padrões. Nesse aspecto, uma das condições que sempre me surpreendeu é a passividade de nossos leitores. Não é crível que entre sete mil (ou mais, já que uma revista pode ser lida por mais de uma pessoa) sequer um deles tenha qualquer questionamento despertado entre os variados artigos de nossas publicações. Alternativa absurda seria a de imaginar que todas as matérias publicadas sejam perfeitas em planejamento e execução, apresentando conteúdos e análises absolutamente claras e convincentes. Ou, ainda, que ninguém as lesse. Na verdade, ambas, hipóteses descartáveis. A primeira porque trabalhos, não apenas os científicos, mas os de quaisquer naturezas, são sujeitos a falhas. Um ou outro podem têlas tão pequenas que de efeito nulo, sendo então passíveis de aceitação como excelentes. Mas a regra é que as falhas humanas sejam notadas, em sua maioria... Segunda: que se lê, sabemos. Por acessos a nossos "sites", por citações de nossos artigos em outros, e até por comentários ouvidos aqui e acolá.
Enfim, sobra a inicialmente mencionada perspectiva de passividade, ou indiferença - o nome que se dê não importa - o que ocorre é uma acomodação ao fato, aliás também um traço de nossa cultura e convivência social. Não se reclama. Discussões e polêmicas são encaradas como reprováveis, por simbolizarem lutas de dois egos, teimosos, um tentando destruir o outro. E não há dúvidas de que, realmente, quando ultrapassando limites de respeito, essas altercações mostram-se condenáveis, além de ineficazes. Mas na polêmica bem conduzida, quando o nível civilizado é mantido e a legítima procura da verdade emerge como propósito, não há vencidos. Ganham em robustez as argumentações lógicas e consistentes, pela incorporação de abordagens mais didáticas a pontos antes obscuros e que deixavam dúvidas em suas linhas expositivas. Ganham aqueles cuja argumentação mostrou-se insuficiente, pela resultante e necessária correção de seus pontos de apoio. Ganham os que presenciam os debates, pela oportunidade de confrontar idéias muitas vezes convergentes ao núcleo da questão, ainda que por vertentes diferentes; ou até substantivamente divergentes, mas quase sempre enriquecedoras. De fato, nem sempre há uma única verdade ou razão, assim como, já dito, não há um artigo tão completo ou perfeito que não suscite reparos.

Utilíssimos, pois, seriam os comentários encaminhados, como Cartas aos Editores, inquirindo sobre um artigo, contestando-o, agregando-lhe argumentos, corrigindo seus dados (em todos os casos, contribuições importantíssimas à ciência). Nelas se consolida a riquíssima oportunidade para os leitores atuarem como analistas suplementares de um trabalho, como comentadores de rumos tomados pela ciência e suas possíveis implicações, como contribuintes de informações, como protagonistas de interações modeladoras da revista.

Cartas aos editores são também oportunas para relatos curtos e comunicações de interesse, mas que não caibam como artigos científicos. Soluções encontradas na aplicação de um método ou de uma técnica, resultados de uma casuística numa cidade ou região (e cuja validade de publicação, como artigo propriamente dito, fica prejudicada pela reiteração de dados, já conhecidos), opiniões sobre custos de procedimentos e tudo o mais que possa enriquecer o acervo de conhecimentos técnicos e práticos da Oftalmologia, contribuindo para o seu ensino ou seu exercício, em consultórios ou laboratórios.

Curiosamente, seja por acomodação, seja por timidez de exposição, seja por receio de possível confronto, poucas são essas manifestações. E há quantidades apreciáveis de questionamentos convenientes e cabíveis em comentários dos 
conselheiros editoriais sobre um trabalho, que ficam apenas nos bastidores de uma publicação e que poderiam ter sido debatidos no texto final: sugestões sobre modificações do método empregado, ou sobre outro enfoque de análise dos resultados, ou sobre relações não vislumbradas pelos autores. Entretanto, um excelente analista no sigiloso anonimato de seus comentários talvez se sinta constrangido a fazê-los dando seu nome a publicação. Perdem os leitores, perde a ciência. Para estimular o desenvolvimento da enriquecedora seção de Cartas aos Editores estaremos, doravante, nos casos em que debates possam ser convenientes e frutíferos, encomendando comentários para que sejam publicamente expostos.

Lembre-se, por fim, que Cartas aos Editores são fontes de dados válidas para indexações e citações, tanto quanto trabalhos convencionais. O que deve representar encorajamentos a participar, emitir opiniões; tudo, obviamente, dentro das convenções de respeito, a veracidade das manifestações sendo pressupostamente assumida. Com isso, o autor estará compelido a produzir esclarecimentos, debater e dar explicações sobre seu trabalho (que apareceriam, de preferência, simultaneamente aos questionamentos ou comentários), uma vigorosa condição de amadurecimento científico; ou, eventualmente, omitir-se à resposta, sempre um seu direito.

Espera-se, com isso, dinamizar essa tão importante seção. A conferir.

Neste número, inclui-se também como mensagem, um texto do Presidente do Conselho Federal de Medicina, sobre a dignidade de ser médico e suas responsabilidades, bem afinado com os pressupostos compromissos de nossa revista com a valorização integral da Oftalmologia.

\title{
IV CONGRESSO DA SOCIEDADE CAIPIRA DE OFTALMOLOGIA
}

\author{
2 e 3 de julho de 2004 \\ Centro de Convenções \\ do Hospital das Clínicas de \\ Ribeirão Preto - SP
}

Informações e Inscrições: CENACON

Tel.: (17) 235-7017/ Fax: (17) 235-5334

E-mail: cenacon@cenacon.com.br

Home-page: www.cenacon.com.br 